\title{
Hydroxyurea Induces Bone Marrow Mesenchymal Stromal Cells Senescence and Modifies Cell Functionality In Vitro
}

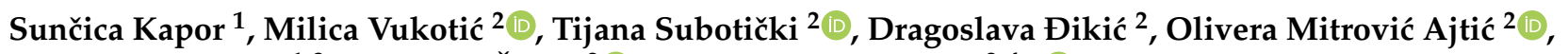 \\ Milica Radojković ${ }^{1,3}$, Vladan P. Čokić ${ }^{2}$ and Juan F. Santibanez ${ }^{2,4, *}$ (i) \\ 1 Clinical Hospital Center "Dr Dragiša Mišović-Dedinje", Department of Hematology, University of Belgrade, \\ 11000 Belgrade, Serbia; suncicabjelica@gmail.com (S.K.); milicaradojkovic1@gmail.com (M.R.) \\ 2 Group for Molecular Oncology, Institute for Medical Research, National Institute of Republic of Serbia, \\ University of Belgrade, 11129 Belgrade, Serbia; milica.tosic@imi.bg.ac.rs (M.V.); tijana@imi.bg.ac.rs (T.S.); \\ dragoslava@imi.bg.ac.rs (D.Đ.); oliveram@imi.bg.ac.rs (O.M.A.); vl@imi.bg.ac.rs (V.P.Č.) \\ 3 Faculty of Medicine, University of Belgrade, 11000 Belgrade, Serbia \\ 4 Centro Integrativo de Biología y Química Aplicada (CIBQA), Universidad Bernardo O’Higgins, \\ General Gana 1780, Santiago 8370854, Chile \\ * Correspondence: jfsantibanez@imi.bg.ac.rs; Tel.: +381-11-2685-788; Fax: +381-11-2643-691
}

\section{check for} updates

Citation: Kapor, S.; Vukotić, M.; Subotički, T.; Đikić, D.;

Mitrović Ajtić, O.; Radojković, M.; Čokić, V.P.; Santibanez, J.F.

Hydroxyurea Induces Bone Marrow Mesenchymal Stromal Cells Senescence and Modifies Cell Functionality In Vitro. J. Pers. Med. 2021, 11, 1048. https://doi.org/ 10.3390/jpm11111048

Academic Editor: Drenka Trivanovic

Received: 14 September 2021

Accepted: 15 October 2021

Published: 20 October 2021

Publisher's Note: MDPI stays neutral with regard to jurisdictional claims in published maps and institutional affiliations.

Copyright: (C) 2021 by the authors. Licensee MDPI, Basel, Switzerland. This article is an open access article distributed under the terms and conditions of the Creative Commons Attribution (CC BY) license (https:/ / creativecommons.org/licenses/by/ $4.0 /)$.

\begin{abstract}
Hydroxyurea (HU) is an antineoplastic agent that functions as an antimetabolite compound by inhibiting the ribonucleotide reductase. HU acts mainly as a cytostatic drug that through DNA replication stress may trigger a premature senescence-like cell phenotype, though its influence on bone marrow-derived mesenchymal stem/stromal cell (BMMSC) functions has not elucidated yet. Our results indicate that $\mathrm{HU}$ inhibits the growth of human BMMSC alongside senescence-like changes in both morphology and replicative potential, provokes cell cycle arrest at the $S$ phase without affecting cellular viability and induces the expression of senescence-associated $\beta$-galactosidase and p16INK4. Moreover, HU-induced senescent BMMSC, although they did not change MSC markers expression, exhibited reduced capacity osteogenic and adipogenic differentiation. Conversely, HU treatment increased immunoregulatory functions of BMMSC compared with untreated cells and determined by T-cell proliferation. Interestingly, HU did not influence the capacity of BMMSC to induce monocytic myeloid-derived suppressor cells. Thus, these results suggest that HU improves the BMMSC functions on the T-cell inhibition and preserves their interaction with myeloid cell compartment. Mechanistically, BMMSC under HU treatment displayed a downregulation of mTOR and p38 MAPK signaling that may explain the reduced cell differentiation and increased immunomodulation activities. Together, the results obtained in this investigation suggest that HU by inducing senescence-like phenotype of BMMSC influences their cellular differentiation and immunoregulatory functions.
\end{abstract}

Keywords: hydroxyurea; bone marrow mesenchymal stem cells; senescence; differentiation; immunosuppression

\section{Introduction}

Hydroxyurea (HU, also named hydroxycarbamide) is non-alkylating antineoplastic and antiviral drug, which functions as an antimetabolite compound due to its inhibitory function on ribonucleotide reductase (RNR). Inhibition of DNA replication by HU is reversible, indicating that the drug is likely a cytostatic agent [1]. This agent has been used to treat neoplastic diseases and non-neoplastic conditions such as infectious and dermatology diseases [1]. Because of all the positive effects of HU therapies, it is nominated as an "essential medicine" by the World Health Organization [2]. Moreover, hydroxyurea is a first-line cytoreduction agent in high-risk patients with a myeloproliferative neoplasm [3].

Mesenchymal stromal/stem cells (MSCs) are crucial elements of the bone marrow (BM) niche where they provide newly formed osteoblasts for bone tissue regeneration and 
tightly control hematopoietic stem cells (HSCs) fate $[4,5]$. They are characterized by the expression of surface markers CD73, CD90, and CD105, and lack of hematopoietic lineage markers expression [6,7]. Furthermore, MSCs are also characterized by expressing low MHC class I and no MHC class II and costimulatory molecules CD40, CD80, and CD86 expression, thus preventing alloreactive antibody production and their elimination by the immune system after transplantation [8].

MSCs are multipotent cells characterized by their ability to differentiate into adipocytes, chondrocytes, and osteoblasts [4,5]. Besides, MSC differentiation is tightly regulated by several intracellular signaling that drive the fate of differentiation [9]. In this sense, the mammalian target of rapamycin (mTOR), a member of the phosphatidylinositol 3-kinaserelated kinase family of protein kinases, regulates MSC committed and critically influences osteogenic and adipogenic differentiation [10-12].

MSCs were initially studied for their ability to support hematopoietic stem cells in the bone marrow $[4,5]$. However, they are now being recognized for their regenerative and immunomodulatory properties, as they home into injured tissues and contribute to tissue repair and suppression of inflammatory damage [13-15]. In particular, MSCs can sense inflammatory signals and adopt a pro- or anti-inflammatory phenotype to modulate innate and adaptive immunity [15]. For instance, MSCs suppress the proliferation of CD4+ $\mathrm{T}$ cells, CD8+ T cells, while promoting the generation of myeloid-derived suppressors cells (MDSC) that further increase local and systemic immunosuppression [16-18]. Moreover, MSC may also infiltrate the tumor microenvironment, contribute to tumor growth, and increase resistance to chemotherapy $[19,20]$.

Chemotherapy, beyond its function in controlling the progression of hematological and solid neoplasms, can influence the function and cellular distribution of BM niches by altering cellular and molecular pathways and modifying transformed cells' behavior [21,22]. In MSC, chemotherapy may induce myelosuppression, and influences their MSCs biological functions, which leads to complications of bone tissue, such as bone fragility because of the decrease in osteoblasts number [23-27]. Moreover, chemotherapy can promote cellular senescence in non-cancerous cells, including fibroblasts and MSCs, which profoundly influence their biological functions [28,29].

We previously demonstrated that $\mathrm{HU}$ induces a senescence-like phenotype in peripheral blood MSCs, which reduces its capacity to support human erythroleukemia cell proliferation in vitro [30]. However, whether HU influences the inherent biological MSCs roles is not well elucidated so far. In this study, we investigated if HU may alter human BMMSC differentiation and immunosuppressive functions. Our results suggested that HU-induced BMMSC senescence, including cell proliferation arrest, reducing cell differentiation while increasing immunosuppressive activity on immune T-cell likely via downregulation of mTOR signaling.

\section{Materials and Methods}

Reagents: The following reagents were used: Anti-CDKN2A/p16 ${ }^{\mathrm{INK} 4 \mathrm{~A}}$ antibody (1D7D2A), obtained from Abcam (Cambridge, UK). Anti-p21 ${ }^{\text {Cip1 }}$ was provided by DakoCytomation A/S (Glostrup, DK). Anti- $\beta$-actin was from R\&D Systems (Minneapolis, MN, USA). Antibodies against phospho-ERK1/2T202/Y204), phospho-p38 and p38, phospho-mTOR and mTOR were purchased from Cell Signaling Technology Inc. (Beverly, MA, USA). HU, CFSE, propidium iodide (PI), Diamidine-2'-phenylindole dihydrochloride (DAPI), Dimethylthiazol-2yl-2,5-diphenyltetrazolium bromide (MTT), doxorubicin, and Everolimus were provided by Sigma-Aldrich Chemie GmbH (Minneapolis, MN, USA).

Cells and culture conditions: Human MSCs were isolated from the iliac crest bone marrow of healthy voluntary donors and isolated as published previously [31] and cultured in a-Modified Eagle Medium supplemented with 10\% fetal bovine serum (FBS) (SigmaAldrich Chemie $\mathrm{GmbH}$, Minneapolis, MN, USA). Cells were then propagated until passage three and used for characterization by flow cytometry. Exponentially growing cells passage 3 to 8 , were used for indicated experiments. PBMSC were isolated as is described in [30]. 
Informed consent was obtained from all of the participants included in the study, which has been approved by the Ethical Committee of the Institute for Medical Research, University of Belgrade. MSCs derived from three different donors were used in this study (Age average: 45 years old).

HS-5 (CRL-11882 ${ }^{\mathrm{TM}}$ ) cells were purchased from the ATCC (Manassas, VA, USA) and were grown in Dulbecco's Modified Eagle Medium (SIGMA-Aldrich, Minneapolis, MN, USA) supplemented with $10 \%$ FBS. Cells were maintained at $37^{\circ} \mathrm{C}$ in a humidified incubator with $5 \% \mathrm{CO}_{2}$ and medium was replaced every $2-3$ days.

Mesenchymal stem cells characterization: To perform the MSCs immunophenotyping, cells at third-passage were stained with fluorescent dye-conjugated antibodies specific for the following human cell-surface antigens: CD11b-PE, CD45-FITC, CD73-APC, CD90-PE, CD105-FITC, (Biosource, Thermo Fisher Scientific, Waltham, MA, USA). Immuno-labelled cells were evaluated using CyFlow CL (Partec, Munster, Germany). For each sample, at least 10,000 events were recorded.

BM-MSC differentiation

To determine the BMMSCs' multipotency capacity, the differentiation into osteocyte and adipocyte lineages were assessed in the presence or absence of $200 \mu \mathrm{M} \mathrm{HU}$. Of note, $\mathrm{HU}$ was added in the induction medium and at the onset of differentiation and replaced with fresh HU every 2 days. For osteogenic differentiation, cells $\left(5 \times 10^{4}\right.$ cells / well) were seeded in 24-well plates and cultured with a specific induction medium (50 mM ascorbic acid, $10 \mathrm{mM} \beta$-glycerophosphate, $100 \mathrm{nM}$ dexamethasone in DMEM/10\% FBS, (all reagents obtained from Sigma-Aldrich Chemie GmbH, Germany) with or without HU for three weeks. The osteogenic differentiation was assessed by inverted light microscope equipped with a digital camera (model, company) after Alizarin red staining.

Adipogenic differentiation of BMMSC was induced by culturing the cells in adipogenic induction medium (500 $\mu \mathrm{M}$ isobutyl-methylxanthine, $500 \mathrm{nM}$ dexamethasone, $50 \mu \mathrm{M}$ indomethacin, $1 \mu \mathrm{M}$ rosiglitazone, and $0.1 \mathrm{UI} / \mathrm{mL}$ insulin diluted in DMEM/10\% FB (all obtained from Sigma-Aldrich Chemie GmbH, Minneapolis, MN, USA) with or without HU for three weeks. Cells were then subjected to Oil-Red staining assay, photographed with an inverted light microscope and densitometry analyses were performed by using J-image software (https://imagej.nih.gov, accessed on 20 November 2020) of at least five microphotographs.

Viability assays:

Cellular viability after antimetabolite treatment was assessed by the MTT assay. Briefly, $5 \times 10^{3}$ cells per well were plated in a 96-well plate $24 \mathrm{~h}$ before treatment with $0,25,50$, 100, 200, 400 and $600 \mathrm{uM} \mathrm{HU}$. Then, cells were allowed to proliferate for $96 \mathrm{~h}$. Following $4 \mathrm{~h}$ incubation with $10 \mu \mathrm{L}$ of $5 \mathrm{mg} / \mathrm{mL}$ MTT solution (Sigma-Aldrich Chemie $\mathrm{GmbH}$, Minneapolis, MN, USA) at $37^{\circ} \mathrm{C}$, supernatants were discarded, and precipitated formazan crystals were dissolved with $100 \mathrm{~mL}$ of DMSO: Isopropanol (2:3) solution for $20 \mathrm{~min}$ at room temperature. Finally, absorbance was measured at $620 \mathrm{~nm}$ using a microplate reader [30].

Cell cycle and apoptosis analysis: Cell cycle phase distribution was determined by staining cells with PI. Cultured cells were treated with $200 \mu \mathrm{M}$ HU for $72 \mathrm{~h}$, harvested, fixed with $70 \%$ ethanol for $30 \mathrm{~min}$ on ice, and stained with propidium iodide (PI) $(50 \mu \mathrm{g} / \mathrm{mL}$ in PBS). DNA contents were examined using a BD FACS Calibur (BD Bioscience, San Diego, CA, USA) and cell cycle phase distribution was analysed using Modfit lt 5 program (Verity Software House, Topsham, ME, USA). Apoptosis was assessed by flow cytometry analysis using the Annexin V-fluorescein isothiocyanate and PI (BD Pharmingen, San Diego, CA, USA) according to the manufacturer's instructions. Flow cytometry analysis was performed using a FACS-Calibur cytometer and Cell Quest software (Becton Dickinson, Heidelberg, Germany).

Immunofluorescence assay: $10^{5}$ cells were seeded on a rounded coverslip in 24 well plates, and $24 \mathrm{~h}$ later, cells were treated with $200 \mu \mathrm{M}$ for $72 \mathrm{~h}$. Then, cells were fixed with $4 \%$ paraformaldehyde in PBS and permeabilized with $0.2 \%$ Triton X-100 for 5 min. Cell monolayers were incubated with anti-p $16^{\mathrm{INK} 4}$ or $-\mathrm{p} 21^{\mathrm{Cip} 1}$, followed by incubation with 
FITC-labelled secondary antibody and $1 \mu \mathrm{g} / \mathrm{mL}$ DAPI. Finally, cells were mounted with DABCO-Mowiol and photographed using an epifluorescence microscope [30].

Senescence-associated- $\beta$-galactosidase assay: Senescence-associated b-galactosidase (SA$\beta$-gal) activity was detected by using Senescence Cells Histochemical Staining Kit (SigmaAldrich Chemie GmbH, Germany) according to manufacturer's instructions. BMMSC were seeded to $50 \%$ confluence and treated with $200 \mu \mathrm{M}$ HU for $72 \mathrm{~h}$. SA- $\beta$-gal positive bluegreen-stained cells were recorded under an inverted light microscope equipped with a digital camera, and at least five randomly chosen fields were counted to determine the percentage of $\beta$-gal positive cells.

Acidic vesicular organelles staining: Acidic vesicular organelles (AVOs) were analysed by vital staining with acridine orange (AO) (Sigma-Aldrich Chemie $\mathrm{GmbH}$, Germany). Acridine Orange is a cell-permeable fluorophore that can be protonated, trapped, and emitting orange fluorescence in acidic vesicular organelles such as lysosomes [32,33]. Briefly, BMMSC treated with $200 \mu \mathrm{M} \mathrm{HU}$ for $48 \mathrm{~h}$ and control cells were incubated with AO $\left(10 \mathrm{mg} / \mathrm{mL}, 30 \mathrm{~min}\right.$ at $\left.37^{\circ} \mathrm{C}\right)$. Then, cells were carefully washed three times with $37^{\circ} \mathrm{C}$ prewarmed PBS and DMEM was added. Fluorescence microphotographs were captured using a fluorescence inverted microscope equipped with a digital camera (model, company).

T-cell proliferation suppression assay: BMMSCs, previously treated for $72 \mathrm{~h}$ with $200 \mu \mathrm{M}$ HU and control samples, were cocultured for five days with $1 \times 10^{5}$ CFSE labelled human peripheral blood mononuclear cells (PBMCs) in RPMI supplemented with 10\% FCS. T cells were activated using $\alpha \mathrm{CD} 3 / \mathrm{CD} 28$ micro-beads (Invitrogen, $\mathrm{UK}$ ) at a concentration of $3 \mu \mathrm{L} / 10^{6} \mathrm{~T}$ cells. At the end of the coculture period, PBMCs were harvested and fixed with $2 \%$ formaldehyde in PBS, and cell proliferation was determined by monitoring CFSE dilution using a BD FACS-Calibur (Becton Dickinson, Heidelberg, Germany).

Myeloid-derived suppressors cells induction: PBMCs were isolated from healthy volunteer donors after density gradient centrifugation on Lymphoprep. MSC previously treated with $200 \mu \mathrm{M}$ HU for $72 \mathrm{~h}$ and control cells were cocultured with PBMCs (ratio 1:5) for five days. Then, PBMCs were collected and subjected to MDSC immune characterization. Monocytic (M)-MDSC subsets were detected by flow cytometry as HLA$\mathrm{DR}^{\text {low } /-} \mathrm{CD} 33^{+} \mathrm{CD} 14^{+} \mathrm{CD} 15^{-}$. Stained cells were analysed by flow cytometry using BD FACS-Calibur (BD Bioscience, San Diego, CA, USA). For each sample, at least 10,000 events were recorded.

Western blot assay: PBMSC were treated for 4, 6, 24, 48, and $72 \mathrm{~h}$ with $200 \mu \mathrm{M} \mathrm{HU}$, whileBMMSC and HS5 cells were treated with $200 \mu \mathrm{M}$ HU for $72 \mathrm{~h}$. Cell monolayers were lysed for $20 \mathrm{~min}$ at $4{ }^{\circ} \mathrm{C}$ in $200 \mu \mathrm{L}$ of lysis buffer (1\% NP-40, 0.5\% Triton-X100 in PBS plus $1 \mathrm{mM} \mathrm{Na} \mathrm{VO}_{4}, 10 \mathrm{mM} \mathrm{NaF}, 10 \mathrm{mM}$ EDTA, and protease inhibitors). Next, protein samples were subjected to SDS-PAGE and electrotransferred to Hybond nitrocellulose membranes (GE Healthcare). Saturated membranes with $4 \%$ non-fat milk, $0.5 \%$ Tween 20 in PBS were incubated with specific primary antibodies, and afterward horseradish peroxidase-conjugated secondary antibodies to (Sigma-Aldrich Chemie $\mathrm{GmbH}$, Minneapolis, MN, USA). Finally, membranes were exposed to an enhanced chemiluminescence detection system and protein band levels were quantified using ChemiDoc Imager and ImageLab software (Bio-Rad, Hercules, CA, USA). PBMSC, BMMSC and HS5 cells were used for Western blot analysis of phospho-mTOR, mTOR, and $\beta$-actin, while BMMSC cells were additionally tested for the expression of phospho-ERK, ERK, phosphor-p38 and p38 proteins.

Statistical analysis: Data are given as means $( \pm$ SEM) from at least three independent experiments. The student's $t$-test was performed to evaluate the probability of significant differences among the samples with $p<0.05\left(^{*}\right)$ and $p<0.005\left(^{* *}\right)$ considered significant.

\section{Results}

\subsection{Bone Marrow Mesenchymal-Stromal/Stem Cells Characterization}

Flow cytometry analysis indicated that isolated BMMSC highly expressed MSCspecific markers CD105 (96.2\%), CD73 (97.1\%), and CD90 (94.6\%), while being negative 
for hematopoietic stem cell markers such as CD11b (0.45\%) and CD45 (0.49\%) (Figure 1A). Moreover, cells showed an ability to adhere to plastic and displayed a spindle-like morphology with long cytoplasmic processes (Figure 1B). Furthermore, cells were able to differentiate into osteocytes (Figure 1C) or adipocytes (Figure 1D) under a specific induction culture medium. Together, these results confirmed the MSCs phenotype of cells isolated from the bone marrow.

(A) Immunophenotypic characterization of BMMSC
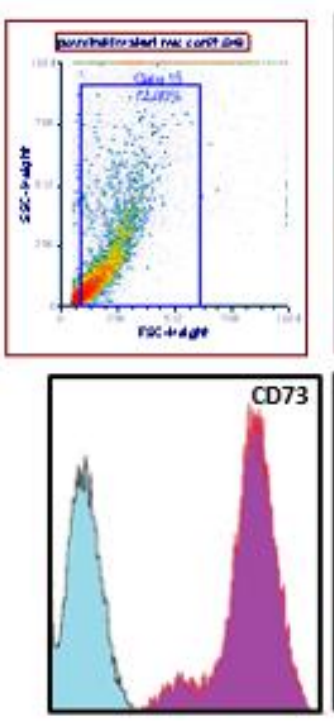

(B)

Undiff. BMMSC

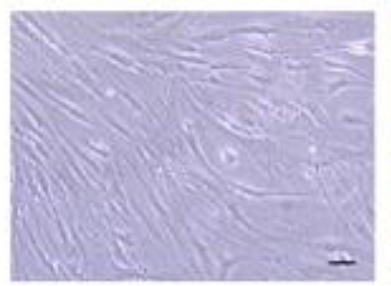

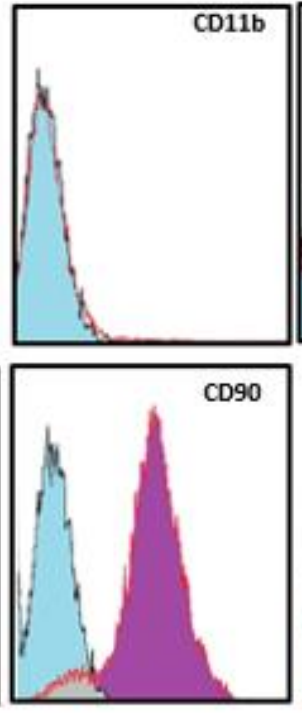

(C) Osteogenic diff.

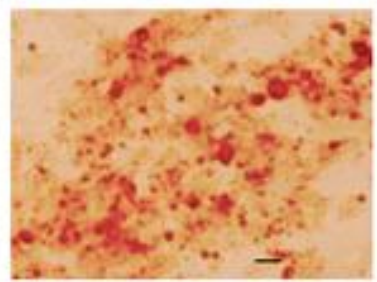

CD45

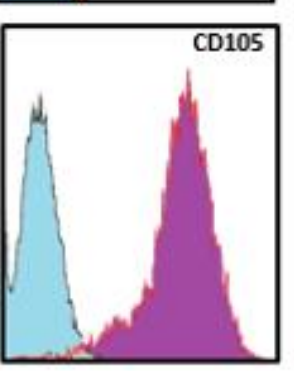

(D)

\begin{tabular}{|c|c|}
\hline$C D$ & $\%( \pm$ SEM) \\
\hline $11 \mathrm{~b}$ & $0.45(0.2)$ \\
\hline 45 & $0.49(0.3)$ \\
\hline 73 & $97.1(2.1)$ \\
\hline 90 & $94.6(1.4)$ \\
\hline 105 & $96.2(1.8)$ \\
\hline
\end{tabular}

Figure 1. Bone marrow Mesenchymal Stem/Stromal cells characterization (A) BMMSC, were subjected to immunophenotyping. Analysis of flow cytometry histogram of BMMSCs for mesenchymal stem cell (CD90, CD73, and CD105) and leukocyte (CD11b and CD45) markers are indicated. Blue light areas indicate background fluorescence obtained with isotype control, and the red-line histogram indicates signal for each specific antibody. Table indicated the average values for the determined cell surface markers. Results presented are representative from at least 3 experiments performed. (B) morphology of undifferentiated BMMSC (C) osteogenic differentiation determined by alizarin red staining for extracellular matrix mineralization; (D) adipogenic differentiation analysed by oilred staining for cytoplasmic lipid drops accumulation. Magnification 40×, Bars $=10 \mu \mathrm{m}$. Results presented are representative from at least 3 performed experiments.

\subsection{Hydroxyurea Reduces Bone Marrow Mesenchymal-Stromal/Stem Cell Proliferation}

$\mathrm{HU}$ possesses cytoreduction properties through its capacity to inhibit cell proliferation, mainly by acting as an antimetabolite compound [1]. BMMSC treated with HU concentrations of 200, 400, or $600 \mu \mathrm{M}$ suffered an increasing inhibition of proliferation as determined by MTT assay (Figure 2A). Because patients' treatment with HU reaches a blood drug concentration of about $200 \mu \mathrm{M}$ [34], we decided to use this clinically relevant drug concentration in the following experiments. BMMSC insulted with HU for three days showed a 
dramatic accumulation in the $S$ phase of the cell cycle, mainly to the detriment of $G_{0} / G_{1}$ phase (Figure 2B). These effects on cell proliferation were not accompanied by inducing cell apoptosis; as demonstrated by Annexin-V/PI apoptosis assay, HU-treated BMMSC did not exhibit major differences in apoptosis compared to untreated cells (Figure 2C).
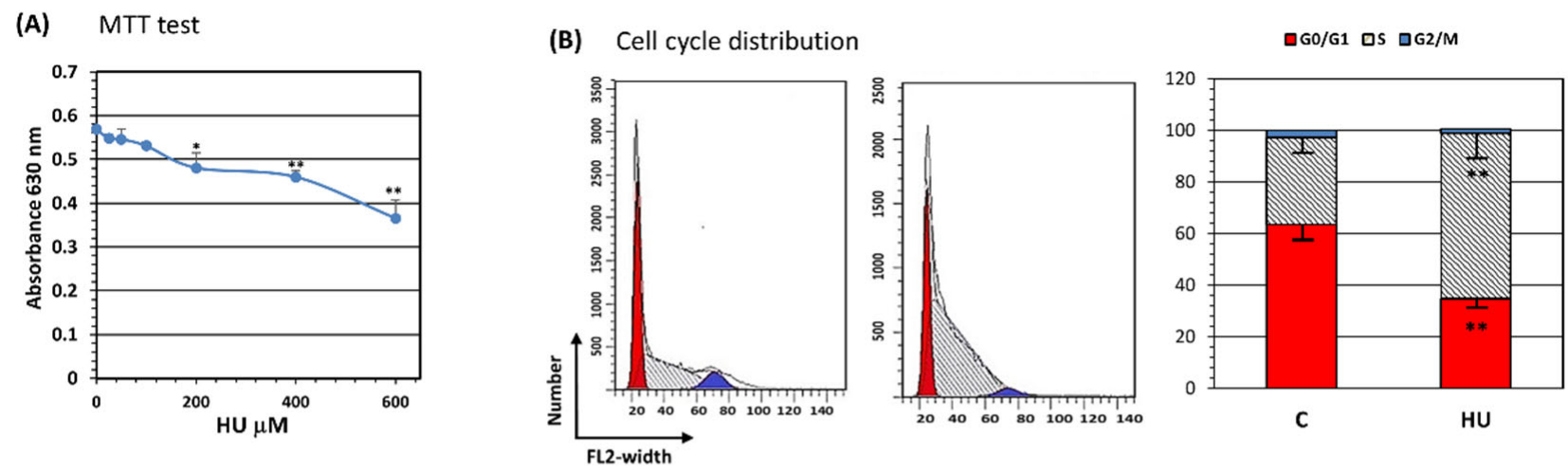

(C)

Apoptosis assay
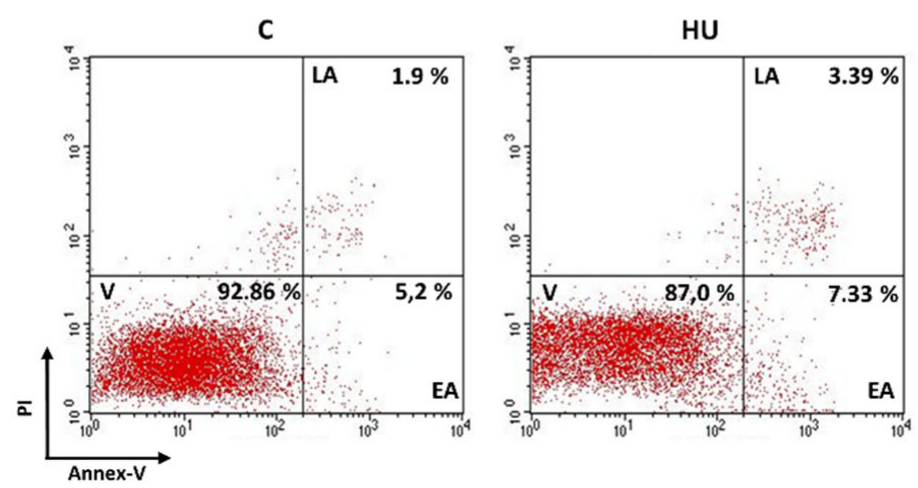

Figure 2. Hydroxyurea inhibits BMMSC proliferation without reducing cell viability. BMMSC were treated for three days with HU and (A) proliferation determined by MTT assay. (B) Cell cycle analysis was performed by flow cytometry. Results indicated that $\mathrm{HU}$ provoked a cell cycle arrest at $\mathrm{S}$ phase. (C) viability/apoptosis analysis was performed. No differences were obtained compared with control cells. PI, propidium iodide; Annex-V, annexin-V; V, Viable cells; EP, early apoptosis; $\mathrm{LP}$, late apoptosis. Results presented are representative from at least 3 performed experiments. Significant difference control cells by $t$-test: $p<0.05\left(^{*}\right)$ and $p<0.005{ }^{(*)}$.

\subsection{Hydroxyurea Induces Bone Marrow Mesenchymal-Stromal/Stem Cells Senescence}

Previous studies from our laboratory and other authors demonstrated that HUinduced proliferation inhibition triggers cell MSC senescence [30,35]. Next, we analysed the HU capacity to induce p $16^{\text {ink4 }}$ and SA- $\beta$-gal expression in BMMSC, both hallmarks of cell senescence phenotype [36]. BMMSC treated for three days with HU expressed increased immunofluorescence positivity to $\mathrm{p} 16^{\text {ink4 }}$ (Figure $3 \mathrm{~A}$ ). Nevertheless, HU-treated cells did not express $\mathrm{P} 21^{\mathrm{CIP}}$; inserted microphotograph indicates positive control for $\mathrm{p} 21^{\mathrm{CIP}}$ expression after treatment of BMMSC with doxorubicin $(100 \mathrm{nM})$. Furthermore, three-day HU treatment-induced SA- $\beta$-gal expression in BMMSC indicated by blue-green staining (Figure 3B). Interestingly, increased SA- $\beta$-gal expression has been associated with lysosome increase in number and size [37]. HU treatment resulted in the appearance of AVOs when the cells were stained with acridine orange after $48 \mathrm{~h}$ of HU treatment (Figure 3C).

\subsection{Hydroxyurea Did Not Influence Surface Marker Expression, Whereas It Reduced Mesenchymal-Stromal/Stem Cells Differentiation}

Since HU inhibition of cell proliferation is accompanied by a senescent phenotype, we next wondered if drug treatment may alter BMMSC stemness properties. We therefore investigated the expression of conventional BMMSC surface markers by flow cytometry 
after three days of HU treatment, MSCs specific markers CD73, CD90, and CD105, were expressed to the similar extent as in (Figure 4B) untreated BMMSC (Figure 4A). As the capacity of BMMSC to differentiate under specific stimuli is their defining stemness property, we investigated whether HU may affect osteogenic and adipogenic differentiation. Decreased calcium deposition on BMMSC monolayers, determined by Alizarin red assay, showed that three days HU treatment significantly reduced osteogenic BMMSC differentiation (Figure 4C). Similarly, adipogenesis was also reduced upon HU treatment, observed by decreased intracellular lipid droplet accumulation after oil red O staining (Figure 4C). Thus, despite maintaining the expression of characteristic stem cell markers, HU-treated BMMSC exhibit reduced differentiation potential compared to untreated cells.

(A)

Immunofluorescence

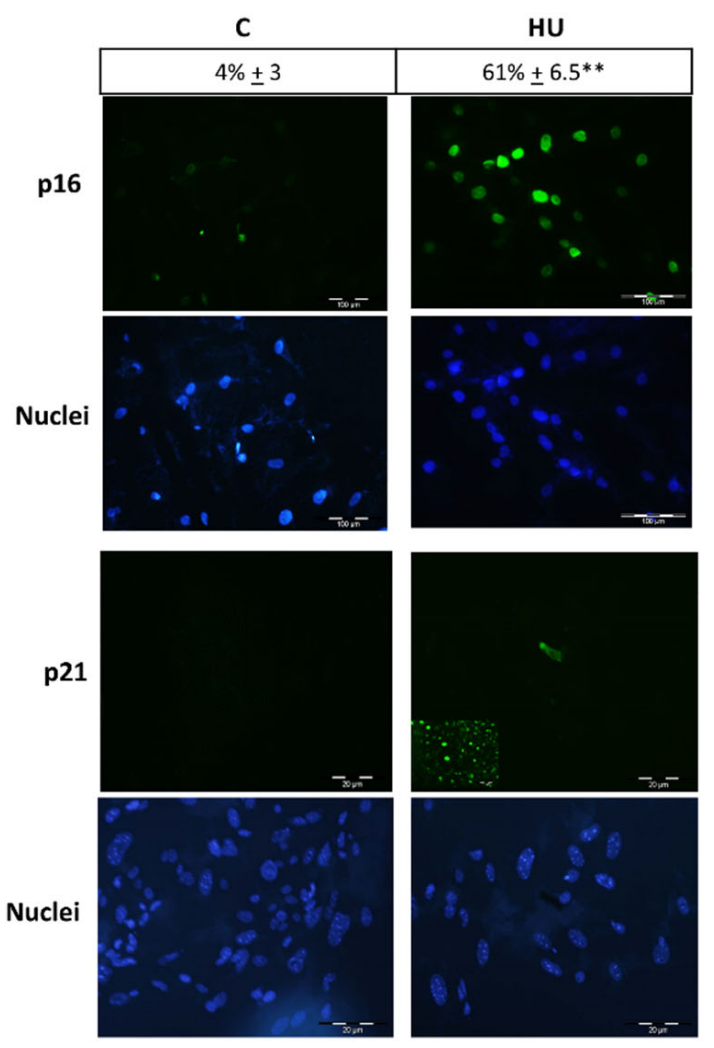

(B)

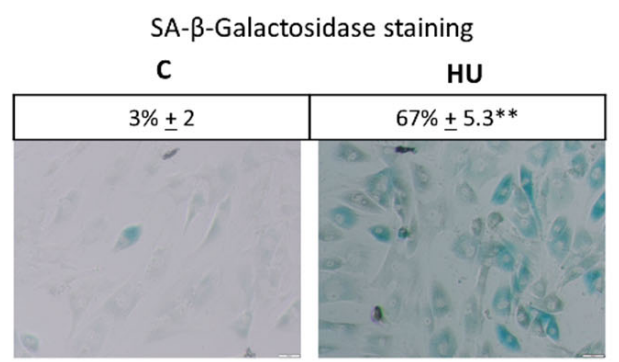

(C)

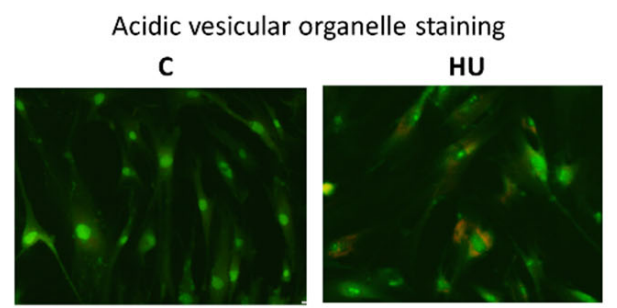

Figure 3. Hydroxyurea induces BMMSC senescence. BMMSC were treated for three days with $200 \mu \mathrm{M}$ of HU (A) fixed and immunostained for p16INK4, magnification $160 \times$, Bars $=100 \mu \mathrm{m}$, or p21Cip1, magnification $240 \times$, Bars $=20 \mu \mathrm{m}$. Corresponding nuclei were stained with DAPI. P21 Cip1 insert, positive control of BMMSC treated with $100 \mathrm{nM}$ of doxorubicin. (B) Subjected to histochemistry analysis for SA- $\beta$-gal observed as blue-green cell staining. Magnification $80 \times$, Bars $=10 \mu \mathrm{m}$. (C) subjected for acidic vesicular organelles (AVOs) staining with acridine orange. Magnification $80 \times$, Bars $=10 \mu \mathrm{m}$. Results presented are representative from at least 3 performed experiments. Significant difference control cells by $t$-test, $p<0.005$ (**).

\subsection{Hydroxyurea Enhances Bone Marrow Mesenchymal-Stromal/Stem Cells Immunosuppression}

Next, we wanted to analyse if HU treatment affects BMMSC functionality. Of note, BMMSCs possess a capacity to reduce T-cell proliferation and activation [38]. To test the effect of HU on BMMSC immunosuppression, we pre-treated BMMSC, or HS-5 bone marrow stromal cells with HU for 3 days, then co-cultured them with PBMC in which T-cell proliferation was activated using $\alpha$ CD3/CD28 micro-beads. Untreated BMMSC and HS-5 cells showed basal inhibitory effect on T-cell proliferation by decreasing the proliferation rate to $65.5 \%$ and $58.4 \%$, respectively, compared to a $100 \%$ proliferation measured in stimulated PBMCs grown in the absence of MSCs (Figure 5). Importantly, HUpre-treated 
BMMSC and HS- 5 cells, exert an increased capacity to inhibit PBMC proliferation compared to untreated, decreasing it to $29.8 \%$ and $28.6 \%$, respectively (Figure 5). HU treatment doubles MSC inhibitory capabilities on T-cell proliferation.

(A)
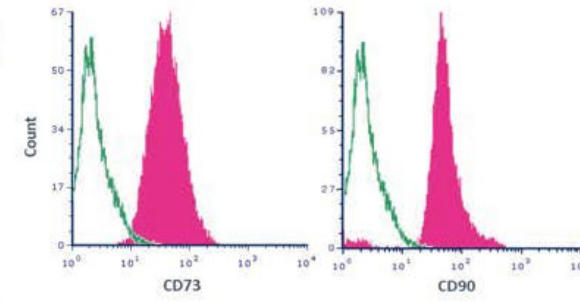

(B)
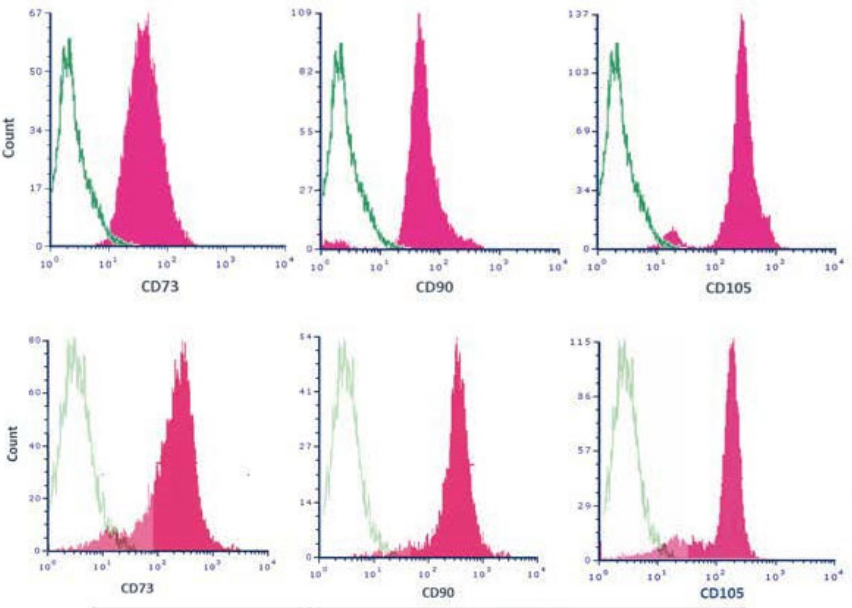

\begin{tabular}{|c|c|}
\hline CD & $\%$ (+ SEM) \\
\hline 73 & $96.91(3.8)$ \\
\hline 90 & $96.9(3.1)$ \\
\hline 105 & $94.43(2.1)$ \\
\hline
\end{tabular}

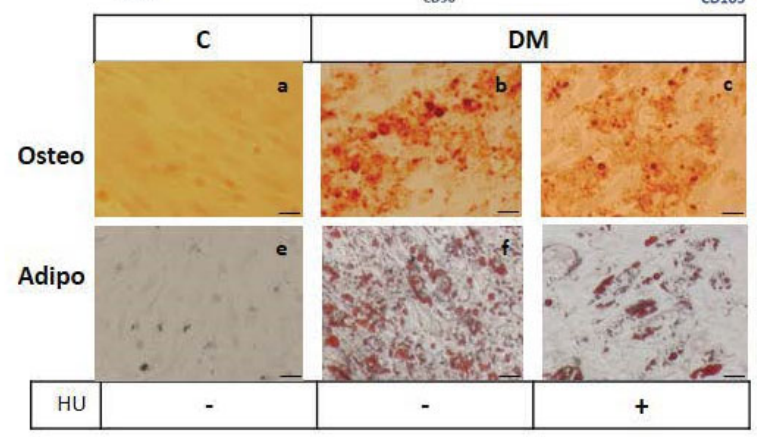

\begin{tabular}{|r|c|c|}
\hline Osteo & 1 & $0.62 \pm 0.09^{*}$ \\
\hline Adipo & 1 & $0.44 \pm 0.11^{* *}$ \\
\hline HU & - & + \\
\hline
\end{tabular}

Figure 4. Hydroxyurea inhibits BMMSC differentiation. BM MSC were cultured for 3 days without (A) or with (B) $200 \mu \mathrm{M}$ HU and subjected to MSC CD73, CD90 and CD105 surface markers determination by flow cytometry analysis. Green line indicated fluorescence obtained with isotype control. (C) Subjected to osteogenic (Osteo) and adipogenic (Adipo) differentiation and determined by alizarin red and oil-red staining respectively. (a,e) non-differentiated control cells, $(\mathbf{b}, \mathbf{f})$ osteogenic differentiation, and $(\mathbf{c}, \mathbf{g})$ adipogenic differentiation. Table indicates the differentiation level compared to BMMSC without HU treatment (value $=1$ ). Magnification $40 \times$, Bars $=10 \mu \mathrm{m}$. Results presented are representative from at least 3 performed experiments. Significant difference control cells by $t$-test: $p<0.05\left(^{*}\right)$ and $p<0.005(* *)$.

\subsection{Hydroxyurea Inhibits mTOR Signaling in Bone Marrow Mesenchymal-Stromal/Stem Cells}

Inhibition of cell proliferation occurs due to decreased proliferative extracellular and intracellular signaling, resulting in cell cycle arrest $[39,40]$. We therefore tested if HU treatment alters the activation of different signalling pathways in MSC. PBMSC subjected to $\mathrm{HU}$ treatments lasting from $4 \mathrm{~h}$ to three days showed that a reduction of mTOR phosphorylation/activation occurs with longer HU exposure of 48-72 h (Figure 6A). mTOR inhibition was further confirmed after three days of HU treatment of BMMSC and HS-5 cells (Figure 6B,C). Nevertheless, mTOR inhibition by $100 \mathrm{nM}$ of Everolimus did not induce BMMSC senescence as determined by SA-b-gal staining (Figure 6D). In addition, HU did not substantially modify ERK1/2 phosphorylation of BMMSC after three treatment days (Figure 6E), while it slightly reduced the expression of downstream phospho-p38, indicating possible involvement of ERK/MAPK signalling pathway (Figure 6F). 


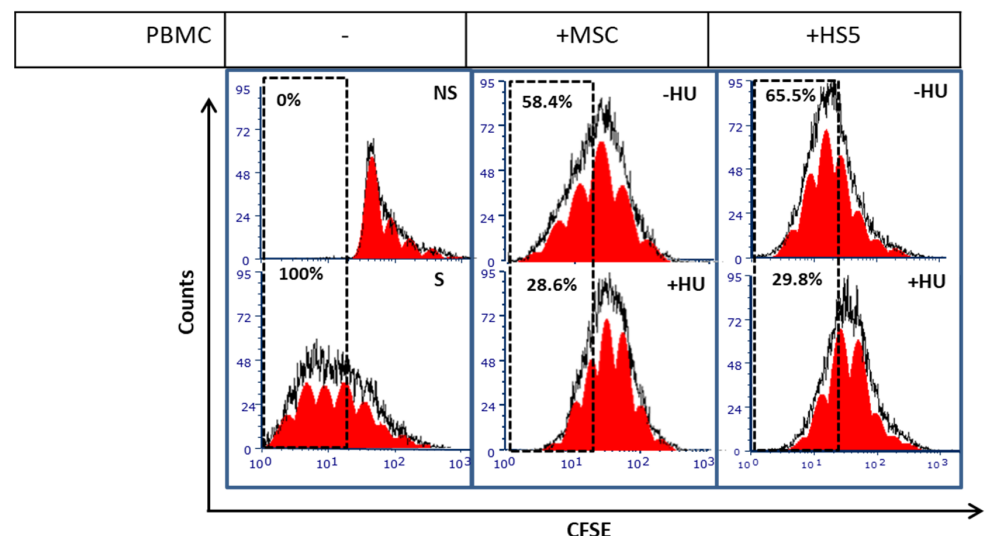

Figure 5. Hydroxyurea enhances the capacity of BMMSC to inhibit T-cell proliferation. BMMSC and HS-5 cell line were pre-treated for three days with $200 \mu \mathrm{M}$ of HU and subjected to co-culture conditions with CFSE-stained peripheral blood mononuclear cells stimulated with $\alpha \mathrm{CD} 3 / \mathrm{CD} 28$ micro-beads for five days. Then, CFSE cellular dilution indicating cellular duplication was analysed by flow cytometry. Experimental control without MSC refers to CFSE-stained PBMC alone under nonstimulated (NS) or stimulated (S) with $\alpha \mathrm{CD} 3 / \mathrm{CD} 28$ conditions. Results presented are representative from at least 3 performed experiments.
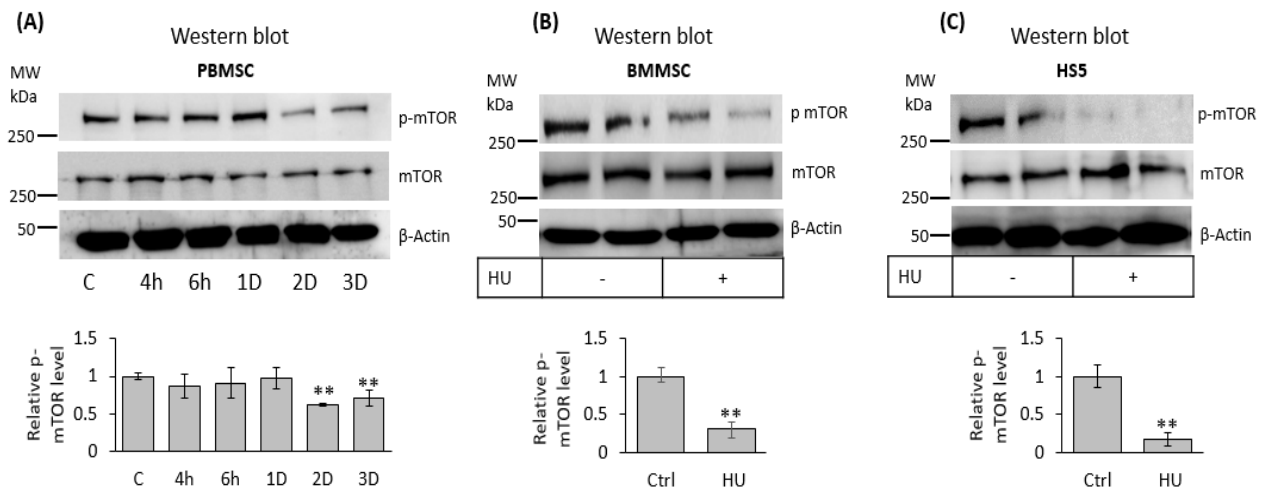

(D)
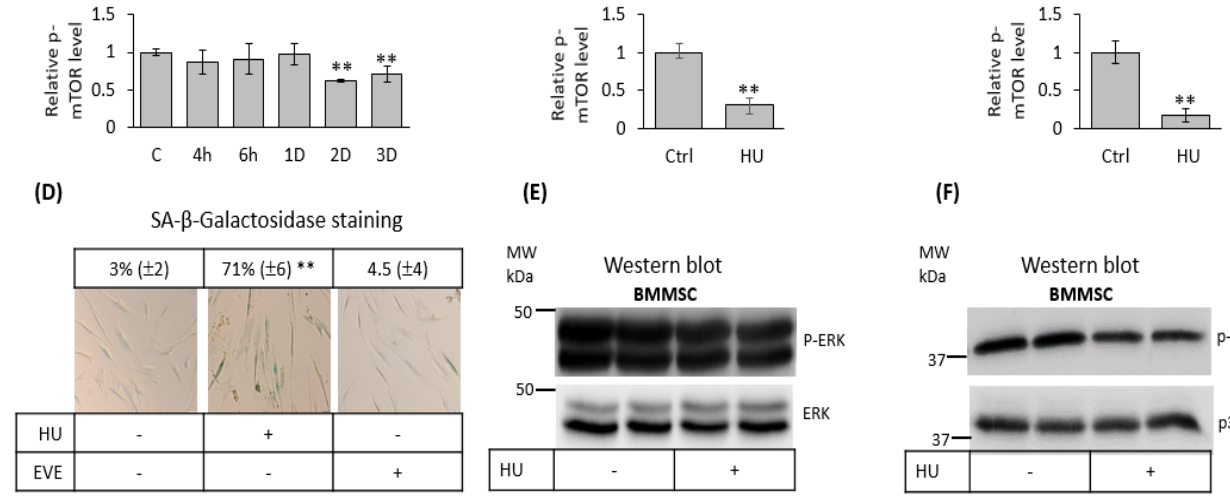

(E)

(F)
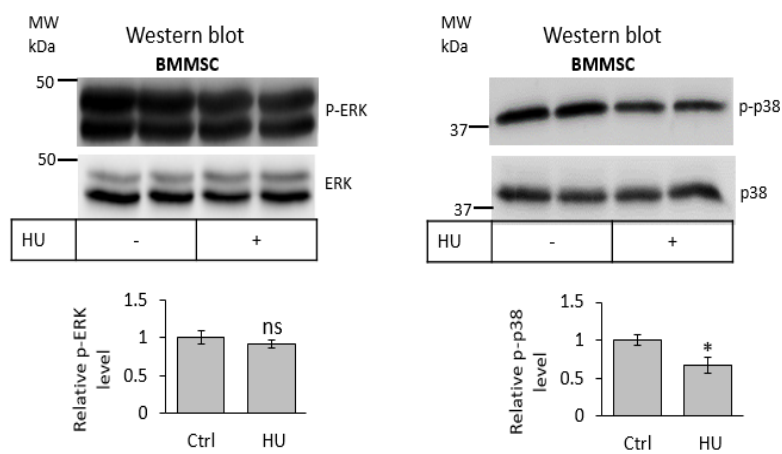

Figure 6. Hydroxyurea inhibits mTOR activation in MSC. (A) PBMSC were treated for the indicated period of time with $200 \mu \mathrm{M}$ HU and subjected to mTOR phosphorylation analysis by Western blot. (B,C) BMMSC and HS-5 cell line treated for three days with $200 \mu \mathrm{M}$ of HU and subjected to mTOR phosphorylation analysis by Western blot. Top tables indicated the relative densitometry values for the obtained signals. $\alpha$-actin is determined as loading control. (D) BMMSC were three days treated with $200 \mu \mathrm{M}$ of HU or $100 \mathrm{nM}$ Everolimus (EVE) and subjected to SA- $\beta$-gal histochemistry assay. (E,F) BMMSC and HS-5 cell line were treated for three days with $200 \mu \mathrm{M}$ of HU and subjected for ERK1,2 and p38 MAPK phosphorylation analysis by Western blot assay. $n=3$, mean \pm SEM, $p<0.05\left(^{*}\right)$ and $p<0.005(* *)$. 


\subsection{Hydroxyurea Did Not Alter Bone Marrow Mesenchymal-Stromal/Stem Cells' Induction of Myeloid-Derived Suppressor Cells}

MSCs further contribute to immunosuppression by inducing MDSC expansion and function [41,42]. Next, we investigated whether HU may influence the capacity of BMMSC to induce the expansion of MDSC. Consequently, we cultured PBMC isolated from healthy subjects with untreated MSC or MSC treated with HU. After five days, the amount of M-MDSC was analysed based on the expression of specific surface markers CD $33^{+} \mathrm{HLA}-$ $\mathrm{DR}^{-} \mathrm{CD} 14^{+}$by flow cytometry. Both control BMMSCs and HU-BMMSCs induce similar M-MDSCs number (Figure 7). Comparable results were observed by co-cultivating HS-5 cells with or without $\mathrm{HU}$ pre-treatment (data not shown). While having a strong inhibitory effect on T-cell proliferation, HU-treated BMMSC do not influence M-MDSC expansion.

(A)

MDSC expansion assay
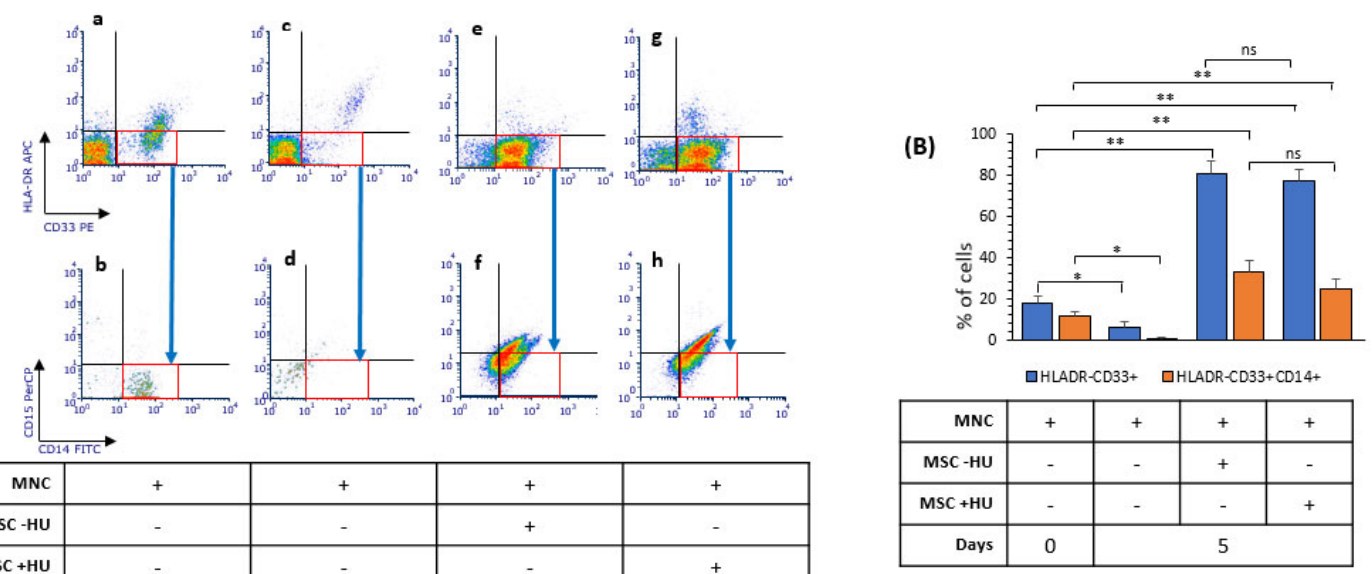

\begin{tabular}{|r|c|c|c|c|}
\hline MNC & + & + & + & + \\
\hline MSC -HU & - & - & + & - \\
\hline MSC +HU & - & - & - & + \\
\hline Days & 0 & \multicolumn{3}{|c}{} \\
\hline
\end{tabular}

Figure 7. Hydroxyurea does not alter the capacity of BMMSC to induce monocytic myeloid-derived suppressor cells expansion. (A) BMMSC were pre-treated for three days with $200 \mu \mathrm{M}$ of HU and co-cultured with-PBMC isolated from healthy donors for five days. Then, PBMC were subjected to immunostaining for HLADR, CD33, CD14, CD15 surface antigens by flow cytometry. Gating was performed to distinguish to populations of cells HLADR-CD33+ cells and M-MDSC (HLADR-, CD33+, CD14+, CD15-) Red squares indicate the selected gating areas for quantification analysis. (B) Bar plot for HLADR-CD33+ cells and M-MDSC quantification. Results presented are representative from at least 3 performed experiments. Significant difference control cells by $t$-test: $p<0.05\left(^{*}\right)$ and $p<0.005\left(^{* *}\right)$.

\section{Discussion}

$\mathrm{HU}$ is a water-soluble antiproliferative agent used in neoplastic and non-neoplastic conditions, such as hematological malignancies, infectious diseases, and dermatology for refractory psoriasis [1]. Mainly, HU arrests cells in the S phase of the cell cycle due to the decrease of dNTPs pools resulting from RNR inhibition and a slowdown of the DNA polymerase movement at replication forks [1,43]. Beyond cancer cells, non-transformed cells are also susceptible to the profound influence of chemotherapy $[44,45]$. Here, we aimed to determine the main aspects of the HU treatment on BMMSC functionality. BMMSC play role in different aspect of cellular and tissue biology, such as tissue regeneration, differentiation, immunomodulation, and as part of the hematopoietic niches [5,46]. Moreover, the BMMSC may infiltrate the tumor microenvironment supporting cancer cell growth, activate mitogen and stress signaling, as well as increase resistance to chemotherapy [19]. Our results indicated that HU effectively reduce BMMSC proliferation with no effect on cell viability, which is in concordance with the notion of that HU acts mainly as a cytostatic agent $[1,43]$.

Cellular senescence is defined as irreversible proliferative cell arrest with secretory features that contributes to aging and age-related diseases [47]. HU belong to the family of anti-metabolite anticancer-drugs, which provoke biological stress and lead to cellu- 
lar senescence in both transformed and non-transformed cells, in a process defined as chemotherapy-induced senescence [48]. Our results indicate that the BMMSC, under HU treatment, display a senescence phenotype as observed by p16INK4 expression and SA$\beta$-gal positivity alongside with lysosome alterations. Interestingly, $\mathrm{HU}$ did not provoke P21CIP expression in BMMSC, similarly to HU-induced senescence in peripheral bloodderived MSC [30]. This is in accordance with literature data showing that HU acts as a replication stress inducer, which alters epigenetic regulation of p16 CDK inhibitor expression, while P21CIP expression depends on DNA damage-induced cellular senescence [28]. Nevertheless, relatively high HU concentration may induce p21CIP stabilization without de novo synthesis in a human embryonic fibroblast cell line or induce p53-p21CIP axis in foreskin fibroblast $[34,49,50]$. Thus, this reinforces the concept of the HU mechanism of senescence depending on the cell type, as well as drug concentration and time of exposure.

MSC play crucial roles in tissue regeneration due to their inherent capacity to differentiate towards different lineages [51]. However, senescent MSC may exhibit, parallel to proliferation arrest, dysfunctional capacity of differentiation, in part due to the profound changes in protein expression and chromosome structure [52,53]. Our results indicated that HU treatment reduced osteogenic and adipogenic differentiation capacity of MSC, without affecting the expression of cell surface markers (Figure 4). Similar results have been reported in dental follicle-derived MSC, where the proliferation and clone formation capacity were impaired by $\mathrm{HU}$ accompanied by reduced MSC differentiation toward adipogenic, chondrogenic, and osteogenic lineages [54]. Conversely, treatment with other antimetabolite drugs-namely, 5-FU and gemcitabine-retain BMMSC multi-lineage differentiation potential, although no senescence analysis was performed in this study [55]. These data suggest that chemotherapy does not modify MSC differentiation markers, thus MSC may preserve their stem identity.

Besides differentiation, MSC also play a role in immune response and inflammation. MSC strongly regulate lymphocyte T-cell proliferation and activation [56,57], which may significantly influence immune surveillance within a tumor microenvironment. In our study, HU greatly enhanced the capacity of BMMSC to inhibit T-cell proliferation (Figure 5). When MSC undergo senescence, they remain metabolically active considerably alter the composition of secretome to senescence-associated secretory phenotype (SASP); transforming growth factor (TGF) $\beta$ is one of the members of SAPs that regulates immune response and strongly inhibit T-cell activation and function [58,59]. HU-induced MSC senescence is accompanied with increased TGF- $\beta$ expression [30], which in part may explain the improved BMMSC capacity to inhibit T-cell proliferation. In addition, senescent mesenchymal-derived cells also produce elevated levels of reactive oxygen species (ROS) [30,60], which may contribute to SASP and suppression of T-cell function [61,62]. Nevertheless, further analyses are necessary to elucidate the exact contribution of TGF- $\beta$ and ROS in the increased capacity of HU-induced MSC senescence.

Interestingly, mTOR signaling plays crucial roles in senescence establishment. This kinase participates in the conversion of cell arrest to senescence phenotype, also called geroconversion, which consider cell cycle inhibition by $\mathrm{p} 16$ or $\mathrm{p} 21$ and active mTOR and ERK1,2 MAPK signaling driving geroconversion towards senescence [63]. Thereby, active mTOR seems to be necessary for the induction of cellular senescence [64,65]. Conversely, our results show that HU-induced MSC senescence provoked a reduction of mTOR activation (Figure $6 \mathrm{~A}-\mathrm{C}$ ). Furthermore, the inhibition of mTOR by Everolimus did not induce BMMSC senescence (Figure 6D), thus suggesting that mTOR inhibition, although it can be necessary, is not sufficient to induce cellular senescence in our experimental conditions. In fact, mTOR inhibition by rapalogs, such as Everolimus, function as a senolytic event with potential use in anti-aging strategies [66]. Moreover, mTOR inhibition prevents the permanent proliferation arrest converting it into a reversible condition [67]. Nonetheless, it is necessary in new experiments to determine the precise mechanism involved in mTOR downregulation and whether this signaling plays roles in pre-senescent and senescent stages of MSC under HU treatment. 
Besides, mTOR signaling tightly regulates the differentiation of MSC reviewed in [10], which may explain decreased differentiation capacity of senescent BMMSC towards osteocyte and adipocyte lineages. Furthermore, mTOR inhibition contributes to an enhanced capacity of MSC to inhibit T-cell proliferation and activation $[68,69]$. Thus, it is possible to speculate that mTOR signaling downregulation by HU during the induction of MSC senescence mediates the inhibition of osteogenic and adipogenic differentiation, as well as contributes to the improvement of the immunomodulatory capacity of BMMSC.

Even though HU did not influence ERK1,2 signaling, it led an inhibition of p38 MAPK that may also contribute to the reduced osteogenic differentiation of senescent BMMSC, since p38 signaling seems to be critical for the committed of MSC toward osteoblastic fate [70]. To date, the underlying molecular mechanism involved in the regulation of intracellular signaling by $\mathrm{HU}$ is not well understood, but it has been suggested that HU may promote epigenetic modifications that may affect several intracellular signal transductions, such as MAPK, PKG, and PKA signaling [71,72].

Finally, HU-induced senescent BMMSC preserve their capacity to induce monocyticMDSC in vitro (Figure 7), indicating that, in part, they capacity to influence myeloid cells is not mainly influenced by HU treatment. Interestingly, the capacity of BMMSC to induce MDSC expansion further contributes to the stabilization of an anti-inflammatory microenvironment that, depending on the disease, may reduce the effectiveness of treatments, such as in cancer, while it may have therapeutic benefits in autoimmune disorders [73].

\section{Conclusions}

HU induces BMMSC senescence alongside reducing cellular differentiation and increasing T-cell immunoregulatory activities, which may be related to inhibition of the mTOR signaling. Our study contributes to the understanding of chemotherapy-induced alterations in bone marrow-derived MSC functionality. Cellular senescence could be a side effect of HU treatment chemotherapy regimens of patients that should be considered in order to avoid harmful treatment-associated comorbidities.

Author Contributions: Conceptualization, J.F.S. and V.P.Č.; Methodology, S.K. and D.Đ.; Validation, J.F.S., M.R. and V.P.Č.; Formal Analysis, J.F.S.; Investigation, S.K., M.V. and T.S.; Data Curation, O.M.A. and D.Đ.; Writing—Original Draft Preparation, J.F.S. and M.V.; Writing—Review \& Editing, J.F.S., M.R. and V.P.Č.; Visualization, J.F.S.; Supervision, J.F.S.; Project Administration, V.P.Č. All authors have read and agreed to the published version of the manuscript.

Funding: Ministry of Education, Science and Technological Development of the Republic of Serbia No 451-03-9/2021-14/200015.

Institutional Review Board Statement: Not applicable.

Informed Consent Statement: Not applicable.

Data Availability Statement: The data presented in this study are available on request from the corresponding author.

Acknowledgments: We thank the support of the visiting professor program of UBO to JFS.

Conflicts of Interest: The authors declare no conflict of interest.

\section{References}

1. Singh, A.; Xu, Y.J. The cell killing mechanisms of hydroxyurea. Genes 2016, 7, 99. [CrossRef] [PubMed]

2. 19th WHO Model List of Essential Medicines (April 2015). Available online: http://www.who.int/medicines/publications / essentialmedicines/EML2015_8-May-15.pdf (accessed on 5 August 2021).

3. Tremblay, D.; Rippel, N.; Feld, J.; El Jamal, S.M.; Mascarenhas, J. Contemporary risk stratification and treatment of chronic myelomonocytic leukemia. Oncologist 2021, 26, 406-421. [CrossRef] [PubMed]

4. Kfoury, Y.; Scadden, D.T. Mesenchymal cell contributions to the stem cell niche. Cell Stem Cell 2015, 16, $239-253$. [CrossRef] [PubMed]

5. Crippa, S.; Bernardo, M.E. Mesenchymal stromal cells: Role in the BM niche and in the support of hematopoietic stem cell transplantation. HemaSphere 2018, 2, 151. [CrossRef] [PubMed] 
6. Dominici, M.; Le Blanc, K.; Mueller, I.; Slaper-Cortenbach, I.; Marini, F.; Krause, D.; Deans, R.; Keating, A.; Prockop, D.J.; Horwitz, E. Minimal criteria for defining multipotent mesenchymal stromal cells. The International Society for Cellular Therapy position statement. Cytotherapy 2006, 8, 315-317. [CrossRef] [PubMed]

7. $\quad$ Pittenger, M.F.; Mackay, A.M.; Beck, S.C.; Jaiswal, R.K.; Douglas, R.; Mosca, J.D.; Moorman, M.A.; Simonetti, D.W.; Craig, S.; Marshak, D.R. Multilineage potential of adult human mesenchymal stem cells. Science 1999, 284, 143-147. [CrossRef]

8. Tse, W.T.; Pendleton, J.D.; Beyer, W.M.; Egalka, M.C.; Guinan, E.C. Suppression of allogeneic T-cell proliferation by human marrow stromal cells: Implications in transplantation. Transplantation 2003, 75, 389-397. [CrossRef]

9. Bhaskar, B.; Mekala, N.K.; Baadhe, R.R.; Rao, P.S. Role of signaling pathways in mesenchymal stem cell differentiation. Curr. Stem Cell Res. Ther. 2014, 9, 508-512. [CrossRef]

10. Xiang, X.; Zhao, J.; Xu, G.; Li, Y.; Zhang, W. mTOR and the differentiation of mesenchymal stem cells. Acta Biochim. Et Biophys. Sin. 2011, 43, 501-510. [CrossRef]

11. Fitter, S.; Matthews, M.P.; Martin, S.K.; Xie, J.; Ooi, S.S.; Walkley, C.R.; Codrington, J.D.; Ruegg, M.A.; Hall, M.N.; Proud, C.G.; et al. mTORC1 plays an important role in skeletal development by controlling preosteoblast differentiation. Mol. Cell. Biol. 2017, 37, e00668-16. [CrossRef]

12. Rhee, Y.H.; Moon, J.H.; Mo, J.H.; Pham, T.; Chung, P.S. mTOR and ROS regulation by anethole on adipogenic differentiation in human mesenchymal stem cells. BMC Cell Biol. 2018, 19, 12. [CrossRef] [PubMed]

13. Di Nicola, M.; Carlo-Stella, C.; Magni, M.; Milanesi, M.; Longoni, P.D.; Matteucci, P.; Grisanti, S.; Gianni, A.M. Human bone marrow stromal cells suppress T-lymphocyte proliferation induced by cellular or nonspecific mitogenic stimuli. Blood 2002, 99, 3838-3843. [CrossRef] [PubMed]

14. Nauta, A.J.; Fibbe, W.E. Immunomodulatory properties of mesenchymal stromal cells. Blood 2007, 110, 3499-3506. [CrossRef]

15. Bernardo, M.E.; Fibbe, W.E. Mesenchymal stromal cells: Sensors and switchers of inflammation. Cell Stem Cell 2013, 13, 392-402. [CrossRef] [PubMed]

16. Müller, L.; Tunger, A.; Wobus, M.; von Bonin, M.; Towers, R.; Bornhäuser, M.; Dazzi, F.; Wehner, R.; Schmitz, M. Immunomodulatory properties of mesenchymal stromal cells: An update. Front. Cell Dev. Biol. 2021, 9, 637725. [CrossRef] [PubMed]

17. Lee, H.J.; Ko, J.H.; Kim, H.J.; Jeong, H.J.; Oh, J.Y. Mesenchymal stromal cells induce distinct myeloid-derived suppressor cells in inflammation. JCI Insight 2020, 5, 136059. [CrossRef] [PubMed]

18. De Cicco, P.; Ercolano, G.; Ianaro, A. The new era of cancer immunotherapy: Targeting myeloid-derived suppressor cells to overcome immune evasion. Front. Immunol. 2020, 11, 1680. [CrossRef] [PubMed]

19. Cammarota, F.; Laukkanen, M.O. Mesenchymal Stem/Stromal Cells in Stromal Evolution and Cancer Progression. Stem Cells Int 2016, 2016, 1-11. [CrossRef] [PubMed]

20. Castellone, M.D.; Laatikainen, L.E.; Laurila, J.P.; Langella, A.; Hematti, P.; Soricelli, A.; Salvatore, M.; Laukkanen, M. Brief report: Mesenchymal stromal cell atrophy in coculture increases aggressiveness of transformed cells. Stem Cells 2013, 31, 1218-1223. [CrossRef]

21. Karagiannis, G.S.; Condeelis, J.S.; Oktay, M.H. Chemotherapy-induced metastasis: Mechanisms and translational opportunities. Clin. Exp. Metastasis 2018, 35, 269-284. [CrossRef]

22. Corazza, F.; Hermans, C.; Ferster, A.; Fondu, P.; Demulder, A.; Sariban, E. Bone marrow stroma damage induced by chemotherapy for acute lymphoblastic leukemia in children. Pediatr. Res. 2004, 55, 152-158. [CrossRef]

23. Wang, Y.; Probin, V.; Zhou, D. Cancer therapy-induced residual bone marrow injury-mechanisms of induction and implication for therapy. Curr. Cancer Ther. Rev. 2006, 2, 271-279. [CrossRef]

24. Kemp, K.; Morse, R.; Wexler, S.; Cox, C.; Mallam, E.; Hows, J.; Donaldson, C. Chemotherapy-induced mesenchymal stem cell damage in patients with hematological malignancy. Ann. Hematol. 2010, 89, 701-713. [CrossRef]

25. Georgiou, K.; Hui, S.K.; Xian, C.J. Regulatory pathways associated with bone loss and bone marrow adiposity caused by aging, chemotherapy, glucocorticoid therapy and radiotherapy. Am. J. Stem Cells 2012, 1, 205-224.

26. Naveiras, O.; Nardi, V.; Wenzel, P.L.; Hauschka, P.V.; Fahey, F.H.; Daley, G.Q. Bone-marrow adipocytes as negative regulators of the haematopoietic microenvironment. Nat. Cell Biol. 2009, 460, 259-263. [CrossRef]

27. Li, S.; Zou, D.; Li, C.; Meng, H.; Sui, W.; Feng, S.; Cheng, T.; Zhai, Q.; Qiu, L. Targeting stem cell niche can protect hematopoietic stem cells from chemotherapy and G-CSF treatment. Stem Cell Res. Ther. 2015, 6, 175. [CrossRef] [PubMed]

28. Petrova, N.V.; Velichko, A.K.; Razin, S.V.; Kantidze, O.L. Small molecule compounds that induce cellular senescence. Aging Cell 2016, 15, 999-1017. [CrossRef]

29. Schmitt, C.A. Senescence, apoptosis and therapy-Cutting the lifelines of cancer. Nat. Rev. Cancer 2003, 3, 286-295. [CrossRef] [PubMed]

30. Bjelica, S.; Diklić, M.; Đikić, D.; Kovačić, M.; Subotički, T.; Mitrović-Ajtić, O.; Radojković, M.; Čokić, V.P.; Santibanez, J.F. Hydroxyurea-induced senescent peripheral blood mesenchymal stromal cells inhibit bystander cell proliferation of JAK2V617Fpositive human erythroleukemia cells. FEBS J. 2019, 286, 3647-3663. [CrossRef] [PubMed]

31. Wagner, W.; Wein, F.; Seckinger, A.; Frankhauser, M.; Wirkner, U.; Krause, U.; Blake, J.; Schwager, C.; Eckstein, V.; Ansorge, W.; et al. Comparative characteristics of mesenchymal stem cells from human bone marrow, adipose tissue, and umbilical cord blood. Exp. Hematol. 2005, 33, 1402-1416. [CrossRef] [PubMed]

32. Thomé, M.P.; Chiela, E.; Villodre, E.S.; Migliavaca, C.B.; Onzi, G.R.; Felipe, K.B.; Lenz, G. Ratiometric analysis of acridine orange staining in the study of acidic organelles and autophagy. J. Cell Sci. 2016, 129, 4622-4632. [CrossRef] 
33. Byvaltsev, V.A.; Bardonova, L.A.; Onaka, N.R.; Polkin, R.A.; Ochkal, S.V.; Shepelev, V.V.; Aliyev, M.A.; Potapov, A.A. Acridine orange: A review of novel applications for surgical cancer imaging and therapy. Front. Oncol. 2019, 9, 925. [CrossRef] [PubMed]

34. Marusyk, A.; Wheeler, L.J.; Mathews, C.K.; DeGregori, J. p53 mediates senescence-like arrest induced by chronic replicational stress. Mol. Cell. Biol. 2007, 27, 5336-5351. [CrossRef] [PubMed]

35. Dong, C.M.; Wang, X.L.; Wang, G.M.; Zhang, W.J.; Zhu, L.; Gao, S.; Yang, D.J.; Qin, Y.; Liang, Q.J.; Chen, Y.L.; et al. A stress-induced cellular aging model with postnatal neural stem cells. Cell Death Dis. 2014, 5, e1116. [CrossRef] [PubMed]

36. González-Gualda, E.; Baker, A.G.; Fruk, L.; Muñoz-Espín, D. A guide to assessing cellular senescence in vitro and in vivo. FEBS J. 2021, 288, 56-80. [CrossRef]

37. Gorgoulis, V.; Adams, P.D.; Alimonti, A.; Bennett, D.C.; Bischof, O.; Bishop, C.; Campisi, J.; Collado, M.; Evangelou, K.; Ferbeyre, G.; et al. Cellular senescence: Defining a path forward. Cell 2019, 179, 813-827. [CrossRef]

38. Wu, X.; Jiang, J.; Gu, Z.; Zhang, J.; Chen, Y.; Liu, X. Mesenchymal stromal cell therapies: Immunomodulatory properties and clinical progress. Stem Cell Res. Ther. 2020, 11, 345. [CrossRef]

39. Pennycook, B.R.; Barr, A.R. Restriction point regulation at the crossroads between quiescence and cell proliferation. FEBS Lett. 2020, 594, 2046-2060. [CrossRef]

40. Boonstra, J.; Moes, M.J. Signal transduction and actin in the regulation of G1-phase progression. Crit. Rev. Eukaryot. Gene Expr. 2005, 15, 255-276. [CrossRef]

41. Yen, B.L.; Yen, M.L.; Hsu, P.J.; Liu, K.J.; Wang, C.J.; Bai, C.H.; Sytwu, H.K. Multipotent human mesenchymal stromal cells mediate expansion of myeloid-derived suppressor cells via hepatocyte growth factor/c-met and STAT3. Stem Cell Rep. 2013, 1, 139-151. [CrossRef]

42. Chen, H.W.; Chen, H.Y.; Wang, L.T.; Wang, F.H.; Fang, L.W.; Lai, H.Y.; Chen, H.H.; Lu, J.; Hung, M.S.; Cheng, Y.; et al. Mesenchymal stem cells tune the development of monocyte-derived dendritic cells toward a myeloid-derived suppressive phenotype through growth-regulated oncogene chemokines. J. Immunol. 2013, 190, 5065-5077. [CrossRef]

43. Nazha, A.; Gerds, A.T. Where to turn for second-line cytoreduction after hydroxyurea in polycythemia vera? Oncologist 2016, 21, 475-480. [CrossRef] [PubMed]

44. Maddika, S.; Mendoza, F.J.; Hauff, K.; Zamzow, C.R.; Paranjothy, T.; Los, M. Cancer-selective therapy of the future: Apoptin and its mechanism of action. Cancer Biol. Ther. 2006, 5, 10-19. [CrossRef] [PubMed]

45. Eckert, M.A.; Orozco, C.; Xiao, J.; Javellana, M.; Lengyel, E. The effects of chemotherapeutics on the ovarian cancer microenvironment. Cancers 2021, 13, 3136. [CrossRef] [PubMed]

46. Pittenger, M.F.; Discher, D.E.; Péault, B.M.; Phinney, D.G.; Hare, J.M.; Caplan, A.I. Mesenchymal stem cell perspective: Cell biology to clinical progress. NPJ Regen. Med. 2019, 4, 22. [CrossRef] [PubMed]

47. Childs, B.G.; Durik, M.; Baker, D.J.; van Deursen, J.M. Cellular senescence in aging and age-related disease: From mechanisms to therapy. Nat. Med. 2015, 21, 1424-1435. [CrossRef] [PubMed]

48. Tiwari, M. Antimetabolites: Established cancer therapy. J. Cancer Res. Ther. 2012, 8, 510-519. [CrossRef] [PubMed]

49. Kim, H.S.; Yeo, E.J.; Park, S.H.; Park, J.I.; Park, S.C.; Shin, J.Y.; Kim, M.J.; Oh, S.J.; Won, M.H.; Kang, T.C.; et al. p21WAF/CIP1/SDI1 is upregulated due to increased mRNA stability during hydroxyurea-induced senescence of human fibroblasts. Mech. Ageing Dev. 2005, 126, 1255-1261. [CrossRef] [PubMed]

50. Yeo, E.J.; Hwang, Y.C.; Kang, C.M.; Kim, I.H.; Kim, D.I.; Parka, J.S.; Choy, H.E.; Park, W.Y.; Park, S.C. Senescence-like changes induced by hydroxyurea in human diploid fibroblasts. Exp. Gerontol. 2000, 35, 553-571. [CrossRef]

51. Visweswaran, M.; Pohl, S.; Arfuso, F.; Newsholme, P.; Dilley, R.; Pervaiz, S.; Dharmarajan, A. Multi-lineage differentiation of mesenchymal stem cells-To Wnt, or not Wnt. Int. J. Biochem. Cell Biol. 2015, 68, 139-147. [CrossRef]

52. Zhou, X.; Hong, Y.; Zhang, H.; Li, X. Mesenchymal stem cell senescence and rejuvenation: Current status and challenges. Front. Cell Dev. Biol. 2020, 8, 364. [CrossRef]

53. Yang, Y.K.; Ogando, C.R.; Wang See, C.; Chang, T.Y.; Barabino, G.A. Changes in phenotype and differentiation potential of human mesenchymal stem cells aging in vitro. Stem Cell Res. Ther. 2018, 9, 131. [CrossRef]

54. Zhai, Y.; Wei, R.; Liu, J.; Wang, H.; Cai, W.; Zhao, M.; Hu, Y.; Wang, S.; Yang, T.; Liu, X.; et al. Drug-induced premature senescence model in human dental follicle stem cells. Oncotarget 2017, 8, 7276-7293. [CrossRef] [PubMed]

55. Lopez Perez, R.; Münz, F.; Vidoni, D.; Rühle, A.; Trinh, T.; Sisombath, S.; Zou, B.; Wuchter, P.; Debus, J.; Grosu, A.L.; et al. Mesenchymal stem cells preserve their stem cell traits after exposure to antimetabolite chemotherapy. Stem Cell Res. 2019, 40, 101536. [CrossRef]

56. Aggarwal, S.; Pittenger, M.F. Human mesenchymal stem cells modulate allogeneic immune cell responses. Blood 2005, 105, 1815-1822. [CrossRef]

57. Glennie, S.; Soeiro, I.; Dyson, P.J.; Lam, E.W.; Dazzi, F. Bone marrow mesenchymal stem cells induce division arrest anergy of activated T cells. Blood 2005, 105, 2821-2827. [CrossRef]

58. Thomas, D.A.; Massagué, J. TGF-beta directly targets cytotoxic T cell functions during tumor evasion of immune surveillance. Cancer Cell 2005, 8, 369-380. [CrossRef]

59. Oh, S.A.; Li, M.O. TGF- $\beta$ : Guardian of T cell function. J. Immunol. 2013, 191, 3973-3979. [CrossRef]

60. Geng, K.; Fu, N.; Yang, X.; Xia, W. Adjudin delays cellular senescence through Sirt3 mediated attenuation of ROS production. Int. J. Mol. Med. 2018, 42, 3522-3529. [CrossRef] 
61. Nelson, G.; Kucheryavenko, O.; Wordsworth, J.; von Zglinicki, T. The senescent bystander effect is caused by ROS-activated NF-KB signalling. Mech. Ageing Dev. 2018, 170, 30-36. [CrossRef] [PubMed]

62. Schmielau, J.; Finn, O.J. Activated granulocytes and granulocyte-derived hydrogen peroxide are the underlying mechanism of suppression of t-cell function in advanced cancer patients. Cancer Res. 2001, 61, 4756-4760.

63. Blagosklonny, M.V. Rapamycin, proliferation and geroconversion to senescence. Cell Cycle 2018, 17, 2655-2665. [CrossRef]

64. Liu, H.; Huang, B.; Xue, S.; Kin, P.U.; Tsang, L.L.; Zhang, X.; Li, G.; Jiang, X. Functional crosstalk between mTORC1/p70S6K pathway and heterochromatin organization in stress-induced senescence of MSCs. Stem Cell Res. Ther. 2020, 11, 1-17. [CrossRef] [PubMed]

65. Saoudaoui, S.; Bernard, M.; Cardin, G.B.; Malaquin, N.; Christopoulos, A.; Rodier, F. mTOR as a senescence manipulation target: A forked road. Adv. Cancer Res. 2021, 150, 335-363. [CrossRef]

66. Blagosklonny, M.V. From rapalogs to anti-aging formula. Oncotarget 2017, 8, 35492-35507. [CrossRef] [PubMed]

67. Demidenko, Z.N.; Zubova, S.G.; Bukreeva, E.I.; Pospelov, V.A.; Pospelova, T.V.; Blagosklonny, M.V. Rapamycin decelerates cellular senescence. Cell Cycle 2009, 8, 1888-1895. [CrossRef]

68. Wang, B.; Lin, Y.; Hu, Y.; Shan, W.; Liu, S.; Xu, Y.; Zhang, H.; Cai, S.; Yu, X.; Cai, Z.; et al. mTOR inhibition improves the immunomodulatory properties of human bone marrow mesenchymal stem cells by inducing COX-2 and PGE2. Stem Cell Res. Ther. 2017, 8, 1-13. [CrossRef] [PubMed]

69. Girdlestone, J.; Pido-Lopez, J.; Srivastava, S.; Chai, J.; Leaver, N.; Galleu, A.; Lombardi, G.; Navarrete, C.V. Enhancement of the immunoregulatory potency of mesenchymal stromal cells by treatment with immunosuppressive drugs. Cytotherapy 2015, 17, 1188-1199. [CrossRef]

70. Rodríguez-Carballo, E.; Gámez, B.; Ventura, F. p38 MAPK signaling in osteoblast differentiation. Front. Cell Dev. Biol. 2016, 4, 40. [CrossRef]

71. Walker, A.L.; Steward, S.; Howard, T.A.; Mortier, N.; Smeltzer, M.; Wang, Y.D.; Ware, R.E. Epigenetic and molecular profiles of erythroid cells after hydroxyurea treatment in sickle cell anemia. Blood 2011, 118, 5664-5670. [CrossRef] [PubMed]

72. Pule, G.D.; Mowla, S.; Novitzky, N.; Wiysonge, C.S.; Wonkam, A. A systematic review of known mechanisms of hydroxyureainduced fetal hemoglobin for treatment of sickle cell disease. Expert Rev. Hematol. 2015, 8, 669-679. [CrossRef] [PubMed]

73. Consonni, F.M.; Porta, C.; Marino, A.; Pandolfo, C.; Mola, S.; Bleve, A.; Sica, A. Myeloid-derived suppressor cells: Ductile targets in disease. Front. Immunol. 2019, 10, 949. [CrossRef] [PubMed] 